\title{
Influence of Age on Tobramycin Pharmacokinetics in Patients with Normal Renal Function
}

\author{
LARRY A. BAUER ${ }^{1 *}$ and ROBERT A. BLOUIN ${ }^{2}$ \\ School of Pharmacy, University of Washington, Seattle, Washington $98195,{ }^{1}$ and College of Pharmacy, \\ University of Kentucky, Lexington, Kentucky $40506^{2}$
}

Received 24 June 1981/Accepted 14 August 1981

\begin{abstract}
The influence of age on tobramycin half-life, volume of distribution, and clearance was examined in 77 patients with infections due to gram-negative bacteria. All patients had normal renal function and hematocrits, were within $20 \%$ of their ideal body weight, did not receive penicillin antibiotics concurrently, and had a fever. Twenty-five patients were between 20 and 39 years of age, 23 patients were 40 to 59 years old, and 29 patients were in the age group 60 to 79 years. The mean half-lives were $2.3,2.2$, and $2.4 \mathrm{~h}$, respectively, for the three age groupings. The average clearance and volume of distribution terms were, respectively, 1.34 $\mathrm{ml} / \mathrm{min}$ per $\mathrm{kg}$ and 0.25 liter $/ \mathrm{kg}$ for the younger group, $1.44 \mathrm{ml} / \mathrm{min}$ per $\mathrm{kg}$ and 0.26 liter $/ \mathrm{kg}$ for the middle age group, and $1.25 \mathrm{ml} / \mathrm{min}$ per $\mathrm{kg}$ and $0.25 \mathrm{liter} / \mathrm{kg}$ for the older group. There was no significant difference among the three groups for any of the parameters $(P>0.05$, analysis of variance). Correlation coefficients determined from individual plots of the three pharmacokinetic parameters versus age revealed no correlation between any parameter and age. Forty-five percent of the patients required doses greater than the recommended maximum $(5 \mathrm{mg} / \mathrm{kg}$ per day) to achieve desired steady-state concentrations. Since tobramycin pharmacokinetics do not change as age increases, doses do not need to be arbitrarily changed in older patients with normal renal function.
\end{abstract}

An understanding of the influence of patients' age on drug disposition is important, particularly when drugs with narrow therapeutic indexes are used, such as the aminoglycoside antibiotics. "High" trough concentrations of these compounds have been associated with nephrotoxicity, and ototoxicity has been associated with elevated peak concentrations $(4,9)$. If aging causes consistent alterations in aminoglycoside pharmacokinetic parameters, dosage changes should be instituted to avoid these side effects. The purpose of this study was to examine the effect that aging has on tobramycin pharmacokinetics in a group of patients with infections due to gram-negative bacteria.

\section{MATERIALS AND METHODS}

Seventy-seven patients with normal renal function (creatinine clearance, $>80 \mathrm{ml} / \mathrm{min}$ per $1.73 \mathrm{~m}^{2}$, measured with a 24-h urine collection) receiving tobramycin for infection with gram-negative bacteria were studied (Table 1). Fifty-seven patients had pneumonias, 12 had lower urinary tract infections, 5 had wound infections, and 3 were treated for sepsis. All were febrile with temperatures ranging from 99.8 to $101.4^{\circ} \mathrm{F}$ (ca. 37.6 to $38.5^{\circ} \mathrm{C}$ ) orally. All patients were within $20 \%$ of their ideal body weight (5), had normal hematocrits, and did not receive penicillins as concurrent therapy.
Tobramycin pharmacokinetic parameters were measured as a part of these patients' medical care. Initial serum concentrations were obtained during the first 2 days of therapy. The elimination rate constant $(K)$ was determined from three postinfusion serum concentrations by using linear regression on a natural logarithm concentration-versus-time graph. Serum specimens were collected $0.25,1$ to 2 , and 3 to $5 \mathrm{~h}$ after a 1-h infusion. Half-life was calculated by dividing the elimination rate constant into 0.693 . The volume of distribution was calculated using the following equation $(11,12)$ :

$$
V=\frac{k_{0}}{K} \frac{1-e^{-K t^{\prime}}}{C_{\max }-\left[C_{\min } \cdot e^{-K t}\right]}
$$

where $k_{0}$ is the tobramycin infusion rate in milligrams per hour, $t^{\prime}$ is the infusion time in hours, $C_{\max }$ is the tobramycin serum concentration in micrograms per milliliter as computed by the regression program immediately after a $1-\mathrm{h}$ infusion, and $C_{\min }$ is the actual serum concentration in micrograms per milliliter immediately before infusion. Total body clearance was calculated as the product of the elimination rate constant and the volume of distribution. This method has been shown to reliably calculate pharmacokinetic constants for aminoglycosides so that doses may be rapidly individualized $(11,12)$. To confirm the validity of this method, actual steady-state $C_{\min }$ and $C_{\max }$ tobramycin serum concentrations were obtained 2 to 3 days after the initial determination and compared with 
those projected using a linear one-compartment intermittent infusion model (8). Doses for each group were adjusted to keep $C_{\max }$ levels between 5 and $8 \mu \mathrm{g} / \mathrm{ml}$ and $C_{\min }$ less than $2 \mu \mathrm{g} / \mathrm{ml}$ at steady state.

The concentrations of tobramycin in serum were measured by radioimmunoassay (Monitor Science). All specimens were analyzed in duplicate and the mean was reported. The coefficient of variation was $7.2 \%$ at $2.5 \mu \mathrm{g} / \mathrm{ml}, 5.1 \%$ at $5 \mu \mathrm{g} / \mathrm{ml}$, and $6.3 \%$ at $10 \mu \mathrm{g} /$ $\mathrm{ml}$. Statistical analysis was performed using one-way analysis of variance for the following age groups: 20 to 39,40 to 59 , and 60 to 79 years. Linear regression was used to examine the influence that the independent variable (e.g., age) had on the dependent variables (e.g., pharmacokinetic parameters). $P<0.05$ was considered statistically significant.

\section{RESULTS}

The pharmacokinetic constants as well as the results of serum creatinine and creatinine clearance measurements are summarized in Table 2. Tobramycin half-life, volume of distribution, and clearance values differed very little with age. There was no significant difference among these groups in the pharmacokinetic parameters that were calculated.

Linear regression was performed on each of the three pharmacokinetic variables versus age. Very poor correlation coefficients $(r)$ were found for total body clearance $(r=-0.002)$, half-life $(r=0.014)$, and the volume of distribution plot $(r=0.071)$. None of these values was statistically significant.

Dosage adjustments were instituted in $82 \%$ of the patients after the initial pharmacokinetic analysis. Doses were increased significantly from $3.4 \pm 0.8$ to $5.6 \pm 0.9 \mathrm{mg} / \mathrm{kg}$ per day $(P<0.01$, paired Student's $t$ test). The projected steadystate levels compared favorably with the measured serum concentrations, being $C_{\max }=7.1 \pm$ $1.0 \mu \mathrm{g} / \mathrm{ml}$ and $C_{\min }=1.2 \pm 0.8 \mu \mathrm{g} / \mathrm{ml}$ whereas the actual measured concentrations were $C_{\max }$ $=6.7 \pm 0.9 \mu \mathrm{g} / \mathrm{ml}$ and $C_{\min }=1.0 \pm 0.7 \mu \mathrm{g} / \mathrm{ml}$.

\section{DISCUSSION}

The effects of age on tobramycin pharmacokinetics have not been systematically studied heretofore. In the study recorded here, this problem was examined in a group of patients who were of widely different ages but were similar with respect to disease state and other conditions known to influence the pharmacokinetics of this aminoglycoside. All patients had normal renal function, were febrile, were within $20 \%$ of their ideal body weight, had normal hematocrits, and did not receive penicillin therapy during this study. Each of these factors influences aminoglycoside disposition $(1-3,6,10)$.

In this relatively homogenous group of patients, there were no significant changes in pharmacokinetic parameters as age increased. There was considerable interpatient variability. For the whole group, the volume of distribution ranged from 0.19 to 0.35 liter $/ \mathrm{kg}$, clearance ranged from 0.72 to $2.40 \mathrm{ml} / \mathrm{min}$ per $\mathrm{kg}$, and the range of halflives was 1.3 to $3.2 \mathrm{~h}$. Sixty-three (82\%) of the patients required a dosage adjustment after the initial pharmacokinetic evaluation. Five patients required a dosage reduction, and 58 needed an increased dose to attain the desired steady-state concentrations. Before individual pharmacokinetic parameters were determined, there was a tendency to underdose patients over $\mathbf{4 0}$ years old; 40 of the patients requiring dosage increases were in this age category. Arbitrary dosage reductions in older patients were most likely made due to the reported general decrease in creatinine clearance with age (7). However, as our data show, elderly patients with creatinine clearance values over $80 \mathrm{ml} / \mathrm{min}$ per $1.73 \mathrm{~m}^{2}$ may be treated with tobramycin and have pharmacoki-

TABLE 1. Characteristics of patient groups studied

\begin{tabular}{cccccc}
\hline $\begin{array}{c}\text { Age group } \\
\text { (yrs) }\end{array}$ & $\begin{array}{c}\text { No. of } \\
\text { patients }\end{array}$ & $\begin{array}{c}\text { Age } \\
\text { (yrs) }\end{array}$ & $\begin{array}{c}\text { Ht } \\
\text { (in.) }\end{array}$ & $\begin{array}{c}\text { Wt } \\
\text { (kg) }\end{array}$ & Sex \\
\hline $20-39$ & 25 & $30.1 \pm 6.1^{a}$ & $67.4 \pm 5.2$ & $72.6 \pm 5.3$ & $15 \mathrm{M}, 10 \mathrm{~F}$ \\
$40-59$ & 23 & $50.5 \pm 5.4$ & $66.1 \pm 6.1$ & $69.8 \pm 6.3$ & $12 \mathrm{M}, 11 \mathrm{~F}$ \\
$60-79$ & 29 & $69.6 \pm 5.7$ & $65.8 \pm 6.7$ & $74.1 \pm 7.1$ & $14 \mathrm{M}, 15 \mathrm{~F}$ \\
\hline
\end{tabular}

${ }^{a}$ Mean \pm standard deviation.

TABLE 2. Pharmacokinetic parameters

\begin{tabular}{cccccc}
\hline $\begin{array}{c}\text { Age group } \\
\text { (yrs) }\end{array}$ & $\begin{array}{c}\text { Serum creatinine } \\
(\mathrm{mg} / \mathrm{dl})\end{array}$ & $\begin{array}{c}\text { Creatinine clearance } \\
\left(\mathrm{ml} / \mathrm{min} \text { per } 1.73 \mathrm{~m}^{2}\right)\end{array}$ & Half-life $(\mathrm{h})$ & $\begin{array}{c}\text { Vol of distribution } \\
(\text { liter/kg) }\end{array}$ & $\begin{array}{c}\text { Total body clearance } \\
\left(\mathrm{ml} / \mathrm{min}_{\text {per }} \mathbf{k g}\right)\end{array}$ \\
\hline $20-39$ & $0.8 \pm 0.2^{a}$ & $104.2 \pm 11.4$ & $2.3 \pm 0.54$ & $0.25 \pm 0.042$ & $1.34 \pm 0.48$ \\
$40-59$ & $0.9 \pm 0.3$ & $100.7 \pm 10.7$ & $2.2 \pm 0.51$ & $0.26 \pm 0.034$ & $1.44 \pm 0.38$ \\
$60-79$ & $0.8 \pm 0.3$ & $97.6 \pm 9.3$ & $2.4 \pm 0.48$ & $0.25 \pm 0.039$ & $1.25 \pm 0.36$ \\
\hline
\end{tabular}

\footnotetext{
${ }^{a}$ Mean \pm standard deviation.
} 
netic parameters comparable to younger patients with similar renal function. It may be particularly useful to individualize doses by serum level concentrations in these older patients in order to rapidly achieve desired concentrations.

The model used to calculate the pharmacokinetic parameters worked very well in attaining the desired steady-state serum concentrations, and this helped to verify the validity of the parameters. The daily tobramycin dose required to achieve the target serum concentrations was $5.6 \pm 0.9 \mathrm{mg} / \mathrm{kg}$ per day, which exceeds the maximum recommended daily dose $(5 \mathrm{mg} / \mathrm{kg}$ per day). Forty-five percent of the patients required doses greater than $5 \mathrm{mg} / \mathrm{kg}$ per day. These results are similar to those recently reported for gentamicin in several patient subgroups (13-15).

In summary, tobramycin pharmacokinetics were not influenced by age in patients with normal renal function. Based on our data, doses do not need to be arbitrarily changed in older patients with normal renal function. Due to the large amount of interpatient variability observed, individualization of tobramycin doses by using serum concentration monitoring may help to rapidly achieve desired steady-state levels.

\section{ITTERATURE CITHD}

1. Barza, M., R. B. Brown, D. Shen, M. Gibaldi, and L. Weinstein. 1975. Predictability of blood levels of gentamicin in man. J. Infect. Dis. 132:165-174.

2. Blouin, R. A. H. J. Mann, W. O. Griften, L. A. Bauer, and $K$. E. Record. 1979. Tobramycin pharmacokjnetics in morbidly obese patients. Clin. Pharmacol.
Ther. 26:508-512.

3. Cutler, R. E., A. M. Gyselynck, P. Fleet, and A. W. Forrey. 1972. Correlation of serum creatinine concentration and gentamicin half-life. J. Am. Med. Assoc. 219:1037-1041.

4. Dahlgren, J. G., E. T. Anderson, and W. L. Hewitt. 1975. Gentamicin blood levels: a guide to nephrotoxicity. Antimicrob. Agents Chemother. 8:58-62.

5. Devine, B. J. 1974. Gentamicin therapy. Drug Intell. Clin. Pharm. 8:650-655.

6. Ervin, F. R., W. E. Bullock, and C. E. Nuttall. 1976. Inactivation of gentamicin by penicillins in patients with renal failure. Antimicrob. Agents Chemother. 9: 1004-1011.

7. Gault, M. H., and D. W. Cockcroft. 1975. Creatinine clearance and age. Lancet ii:612-613.

8. Gibaldi, M., and D. Perrier. 1975. Pharmacokinetics. Marcel Dekker, New York.

9. Mawer, G. E., R. Ahmad, and S. M. Dobbs. 1974. Prescribing aids for gentamicin. Br. J. Clin. Pharmacol. 1:45-50.

10. Pennington, J. E., D. C. Dale, and H. Y. Reynolds. 1975. Gentamicin sulfate pharmacokinetics: lower levels of gentamicin during fever. J. Infect. Dis. 132:270-275.

11. Sawchuk, R. J., and D. E. Zaske. 1976. Pharmacokinetics of dosing regimens which utilize multiple intravenous infusions. J. Pharmacokinet. Biopharm. 4:183195.

12. Sawchuk, R. J., D. E. Zaske, R. J. Cipolle, W. A. Wargin, and R. G. Strate. 1977. Kinetic model for gentamicin dosing with the use of individual patient parameters. Clin. Pharmacol. Ther. 21:362-369.

13. Zaske, D. E., R. J. Cipolle, and R. J. Strate. 1980. Gentamicin dosage requirements: wide interpatient variations in 242 surgery patients with normal renal function. Surgery 87:164-169.

14. Zaske, D. E., R. J. Cipolle, R. G. Strate, and W. F. Dickes. 1981. Increased gentamicin dosage requirements: rapid elimination in 249 gynecology patients. Am. J. Obstet. Gynecol. 139:896-900.

15. Zaske, D. E., R. J. Cipolle, R. G. Strate, J. W. Malo, and M. F. Koskalka. 1980. Rapid gentamicin elimination in obstetric patients. Obstetr. Gynecol. 56:559564. 